\title{
Open Source and Open Data: Business Perspectives from the Frontline
}

\author{
Juho Lindman and Yulia Tammisto \\ Aalto University School of Economics, Information Systems Science, \\ PL 21210, 00076 Aalto, Helsinki, Finland \\ \{Yulia.Tammisto, Juho. Lindman\} @aal to.fi
}

\begin{abstract}
Open data initiatives on governmental data seem often to be linked to small software companies, which also use and release software under OSS licenses. This paper calls for more research to understand the similarities between open data and open source software vendors. We build a theoretical linkage between the more established OSS research and emerging research on open data in the context of small software companies.
\end{abstract}

\section{Introduction}

Governmental Open Data projects in different countries have created new opportunities for small software companies [11], but the possibilities of Open Data $(\mathrm{OD})^{1}$ are not limited to governmental data. A better understanding of the changes in the ecosystems where these small software companies operate helps to better understand the transformation of the software marketplace driven by OD and Open Source Software (OSS) $)^{2}$.

There is a gap in research traditions between research on OSS and OD. This is surprising at the outset, as most OD advocates have invested heavily in OSS; many of the tools used in OD publication are licensed under OSS licenses; and often the actual companies are similar or even operate in both OSS and OD. OD also enjoys a wide popularity in OSS communities. We propose that this gap should be bridged and theoretical linkages built between OSS and OD research.

\section{OSS and OD}

Voluntary collective action systems often include a public or semipublic good [5]. These public goods can be for example OSS or OD. Mixing open and proprietary product strategies offers potential to many software companies [3]. Another way to

${ }^{1}$ OD refers to "information that has been made technically and legally available for reuse" [22]. In addition to the technological details our definition stresses the legal and organizational aspects of open data that are similar in OSS research.

${ }^{2}$ In this paper we rely on the following OSS definition: "Open Source is a development method for software that harnesses the power of distributed peer review and transparency of process" (http://www.opensource.org). 
benefit from more open development is to change internal software production based on the lessons from the OSS world [4]. Concepts used to describe OSS inspired practices within an organization include: Corporate Source [2] and Inner Source [9]. Open Source can also be considered as a sourcing strategy and defined as a governance model, where software development tasks are opensourced to an unknown workforce [13].

Open government data has been claimed to offer possibilities for economic growth by providing data sets which can be used in the provisioning of new services [6]. Tim Berners-Lee [1] has provided a categorization of five levels of open data for linked open data. The process of data transformation and publication can be theorized in several ways. Latif et al. [8] offered a model to describe the roles of entities in OD business: 1) raw data provider, 2) linked data developer and 3) applications developer. Elsewhere [12], we have developed a conceptualization, building on Latif [8] and Rajala's [10] classification, which focuses on the different business models of the actors. Based on our findings, it seems that value capturing (of the small software companies of open data) may follow three different paths: 1) consultancy, 2) conversion, and 3) application development.

\section{Findings}

We conducted a small round of interviews about OD using interpretive interview approach [7] and compared the results with the earlier collected data on OSS. Through the course of the analysis we detected a certain similarities between OSS and OD companies that are reported in Table 1. All the respondents are from Finland, their profiles are listed in Table 2.

Table 1. Similarities between OD and OSS business

\begin{tabular}{|l|l|l|l|}
\hline $\begin{array}{l}\text { Competition } \\
\text { environment }\end{array}$ & $\begin{array}{l}\text { Open Data } \\
\text { Market is divided } \\
\text { between small software } \\
\text { companies and large } \\
\text { software companies }\end{array}$ & $\begin{array}{l}\text { Open Source } \\
\text { between small, } \\
\text { medium- and } \\
\text { large software } \\
\text { companies }\end{array}$ & $\begin{array}{l}\text { Similarity } \\
\text { competitors are the } \\
\text { same in both OD and } \\
\text { OSS. Some companies } \\
\text { are the same and they } \\
\text { use and develop the } \\
\text { same software. }\end{array}$ \\
\hline Customers & $\begin{array}{l}\text { So far emphasis on } \\
\text { public organizations } \\
\text { (cultural institutions, } \\
\text { municipalities), } \\
\text { potential in the media- } \\
\text { industry }\end{array}$ & $\begin{array}{l}\text { Emphasis on } \\
\text { public } \\
\text { organizations } \\
\text { (schools) and } \\
\text { private actors }\end{array}$ & $\begin{array}{l}\text { Public sector as arge } \\
\text { customer }\end{array}$ \\
\hline $\begin{array}{l}\text { Revenue } \\
\text { sources }\end{array}$ & $\begin{array}{l}\text { Consultancy, } \\
\text { conversions, } \\
\text { application } \\
\text { development, } \\
\text { maintenance }\end{array}$ & $\begin{array}{l}\text { Consultancy, } \\
\text { application } \\
\text { development, } \\
\text { maintenance }\end{array}$ & $\begin{array}{l}\text { Not based on traditional } \\
\text { software sales, develop } \\
\text { services on top of } \\
\text { public goods }\end{array}$ \\
\hline
\end{tabular}


Table 1. (Continued)

\begin{tabular}{|l|l|l|l|}
\hline Communities & $\begin{array}{l}\text { Often enjoy popularity } \\
\text { and community support }\end{array}$ & $\begin{array}{l}\text { Often enjoy } \\
\text { popularity and } \\
\text { community } \\
\text { support }\end{array}$ & $\begin{array}{l}\text { Developer-communities } \\
\text { are the same and have } \\
\text { "activist" components }\end{array}$ \\
\hline $\begin{array}{l}\text { Openness of } \\
\text { activities }\end{array}$ & $\begin{array}{l}\text { "I think the added } \\
\text { value [of OD] comes } \\
\text { from having more } \\
\text { clever people to look at } \\
\text { it." }\end{array}$ & $\begin{array}{l}\text { make bugs } \\
\text { shallow" }\end{array}$ & $\begin{array}{l}\text { Favor openness in the } \\
\text { innovation activity }\end{array}$ \\
\hline
\end{tabular}

Table 2. Informants of the interviews

\begin{tabular}{|c|l|l|}
\hline OD & \multicolumn{1}{|c|}{ Company } & \multicolumn{1}{c|}{ Position } \\
\hline 1 & $\begin{array}{l}\text { Small (5 persons) web technology and application } \\
\text { development company }\end{array}$ & $\begin{array}{l}\text { Project manager / } \\
\text { Consultant }\end{array}$ \\
\hline 2 & $\begin{array}{l}\text { Small (5 persons) web technology and application } \\
\text { development company (same as above) }\end{array}$ & $\begin{array}{l}\text { CEO / Consultant / } \\
\text { Developer }\end{array}$ \\
\hline 3 & Small (10 persons) software development company & $\begin{array}{l}\text { Project manager / } \\
\text { Developer }\end{array}$ \\
\hline 4 & $\begin{array}{l}\text { Small (2 persons) consultancy and software } \\
\text { development company }\end{array}$ & CEO / Consultant \\
\hline
\end{tabular}

\begin{tabular}{|c|l|l|}
\hline OS & \multicolumn{1}{|c|}{ Company } & \multicolumn{1}{|c|}{ Position } \\
\hline 1 & $\begin{array}{l}\text { Small (3 persons) OSS company developing } \\
\text { collaborative learning tools }\end{array}$ & CEO \\
\hline 2 & $\begin{array}{l}\text { Small (3 persons) OSS company developing } \\
\text { collaborative learning tools (same as above) }\end{array}$ & Developer \\
\hline 3 & $\begin{array}{l}\text { Small (1 person) OSS company developing relational } \\
\text { database tools }\end{array}$ & Entrepreneur \\
\hline 4 & $\begin{array}{l}\text { Small (10 persons) OSS company developing web } \\
\text { services }\end{array}$ & Developer \\
\hline
\end{tabular}

\section{Conclusion}

The aim of this paper was to look for some similarities between OD and OSS in the context of small software companies engaged in OD and OSS. We speculate that there are interesting lessons to be learned to the OD research from OSS business model research related to service design and delivery relying on public goods. Research on OSS communities can in some cases be applicable also to the emerging OD communities. By this paper we only scratched the surface of the potential contribution for the research. We call for a further research on comparison of OD and OSS to realize all the benefits of the combination of these two phenomena. 


\section{References}

1. Berners-Lee, T.: Linked Data Design Issues (July 2006), http: / / www.w3 .org/DesignIssues / LinkedData.html

2. Dinkelacker, J., Garg, P., Miller, R., Nelson, D.: Progressive Open Source. In: The Proceedings of ICSE 2002, May 19-25, pp. 174-184 (2002)

3. Fosfuri, A., Giarratana, M., Luzzi, A.: The Penguin Has Entered the Building: The Commercialization of Open Source Software Products. Organization Science 19(2), 292305 (2008)

4. Gurbani, V., Garvert, A., Hersleb, J.: Managing a Corporate Open Source Asset. Communications of the ACM 53(2), 155-159 (2010)

5. Heckathorn, D.: The Dynamics and Dilemmas of Collective Action. American Sociological Review 61(2), 250-277 (1996)

6. Huijboom, N., Van den Broek, T.: Open Data: an International Comparison of Strategies. European Journal of ePractice 12 (March/April 2011), http: / /www. epractice. eu/files/European\%2 0Journal\%20 epractice \%20Volume $\% 2012 \_1 . p d f$

7. Klein, H., Myers, M.: A set of Principles for Conducting and Evaluating Interpretative Field Studies in Information Systems. MIS Quarterly 23(1), 67-94 (1999)

8. Latif, A., Saeed, A.U., Hoefler, P., Stocker, A., Wagner, C.: The Linked Data Value Chain: A Light Weight Model for Business Engeneers. In: Proceedings of I-SEMANTICS 2009 International Conference on Semantic Systems, Graz, Austria, pp. 568-575 (2009)

9. Linden, F., Lundell, B., Marttiin, P.: Commodification of Industrial Software - A Case for Open Source. IEEE Software (July-August 2009)

10. Rajala, R.: Determinants of Business Model Performance in Software firms. Doctoral Dissertation, Aalto University School of Economics, Helsinki, Finland (2010)

11. SOMUS. Social media for citizens and public sector collaboration) project - final report (January 2011), http://www.vtt.fi/inf/pdf/publications/2011/P755.pdf

12. Tammisto, Y., Lindman, J.: Open Data Business Models. In: The Proceedings of the 34th IRIS Seminar, Turku, Finland, August 16-19, pp. 16-19 (accepted, 2011)

13. Ågerfalk, P., Fitzgerald, B.: Outsourcing to an Unknown Workforce: Exploring Opensourcing as a Global Sourcing Strategy. MIS Quarterly 32(2), 385-409 (2008) 